\title{
Political Nation and Spatial Order: Towards a New Recombination of the Old Concepts*
}

\author{
Alexander F. Filippov \\ Professor of Sociology, National Research University Higher School of Economics \\ Address: Myasnitskaya Str., 20, Moscow, Russian Federation 101000 \\ E-mail: filippovaf@gmail.com
}

\begin{abstract}
The paper compares opposite approaches to the study of spatial order in contemporary societies. On the one hand, theories of globalization and world society argue that states and their borders are not relevant anymore. Globalization means world without borders, therefore contemporary global cities, being located within state borders, do not belong to their territories. In a global city, there is no room for common solidarity among citizens-those who go beyond state borders cannot become integrated to world society. On the other hand, there is much empirical evidence that states do not disappear. They still play a significant role. The state border deliniates a part of space which people can feel emotional attachment with. The states can use legitimate violence against those who reside within its borders as well as enforce feelings of solidarity with those who live on this territory. This logic brings two notions of nation and nationalism. In a more traditional understanding of these notions based on kinship ("consanguinity"), culture and language, the state is defined as a tool for the constitution of nation, which needs territory with clear borders for survival. In contrast, the civic understanding of nation suggests flexibility of any identities, including the national one. Those who follow the second definition usually do not recognize its implications. On the one hand, a territorially located group can demand statehood to assert and guarantee its identity. On the other hand, a group, which has freely chosen its identity, also can demand spatial borders and, in the same vein, a state. These demands are connected with each other. Spatial definition of any group, which can proclaim itself as a nation and demand a state, contradicts contemporary organization of global cities. In this respect, sociology may be interested in how these two modes of space intersect, i.e. how the world society with its fluids and networks interacts with new states, being constituted within new borders.
\end{abstract}

Keywords: nation, nationalism, global city, world society, state, border

This is the first special issue of the Russian Sociological Review. Herewithin, the Editorial Board of the journal and the Fellows of the Centre for Fundamental Sociology of the Higher School of Economics begin a new series of our online publications. Every year, in addition to the regular three issues of each volume, we will prepare one to two special issues dedicated to the most interesting and contested themes of the social sciences. The present issue includes papers that focus on the problem of "border." Their authors differ in research strategies and theoretical attitudes; they belong to different disciplines and

(c) Alexander F. Filippov, 2014

(c) Centre for Fundamental Sociology, 2014

* The results of the project "Emergent vs Imposed Order of Social Life: The Modes of Interaction and Transformations", carried out within the framework of the Basic Research Program at the National Research University Higher School of Economics (HSE) in 2014, are presented in this work. 
institutions. Now, they meet under the virtual cover of the Russian Sociological Review, not only due to the arbitrariness of the editors, and the rather vague thematic similarity implied by the term "border." In an old-fashioned mode, I would say that it is life itself which breaks through our concepts and theories. The problem of "border" has its own moving force overriding our intentions and ambitions. Contemporary political, cultural, and economic situations change the spatial figures of the social world dramatically; new borders emerge; old borders acquire new transparency or, conversely, a new rigidity; new modes of bordering and different kinds of borders become relevant just here and now. All these transform the very idea of territory and place. Every process, every border emerging and disappearing, is a challenge. We have no convincing answers for these challenges; we only attempt to find these answers.

That was the reason to disseminate our call for papers in different social networks for social scientists. Surprisingly, we had received a few dozen proposals very soon. Almost all of them were very interesting; however, different obstacles prevented us from publishing more than half of the papers that were received. We shall publish another part of them next year in our regular issues. Now, I would like to express my deep gratitude to all those who responded to our call for papers, and to those colleagues who wrote reviews.

I also cannot fail to mention one significant event that gave me, as the editor-in-chief of the RSR, an additional impetus to start our publication series with this "borders" issue. Early in June of 2014, I participated as a keynote speaker at the first World Conference of the Association of Borderlands Studies in Joensuu, Finland. I was deeply impressed by the variety and quality of research presented there. I am grateful to the Karelian Institute, University of Eastern Finland, and to Professor Ilkka Liikanen, who is one of the authors of this issue, for their invitation. I would like to take the opportunity to publish my slightly-modified short paper here, instead of a more conventional editor's introduction.

It was not by coincidence that the theories of a new, borderless world began their short but bright career in the social sciences in the early 1990s, an extraordinary time, especially in Europe. A number of the old borders disappeared, for example, the border between East and West Germany, and between NATO and the Warsaw Pact. However, at the same time, new borders emerged. For example, the Soviet Union collapsed, and the union republics became states with their territorial borders (these borders stayed transparent for a short time and then became more established, at least in several cases). As well, other countries like Yugoslavia and Czechoslovakia disintegrated. As a result, the number of states and borders has not diminished, but increased. What is more intriguing in this regard is that, in the social sciences, the concept of globalization has dominated. Globalization was seen as the emergence of a united world without borders. 
The title of the famous book by Kenichi Ohmae, The Borderless World (1990), was the motto of the nineties. ${ }^{1}$ However, sociologists were largely cautious about it; they tried to demonstrate that globalization does not mean the unification and total Westernization of the world. Roland Robertson argued in his famous Globalization that the time of the early nineties was the "phase of uncertainty" and that globalization does not mean integration. ${ }^{2}$ Such terms as "glocalization" and "hybridization" were attempts to counteract the very tempting ideas of a new homogeneous unity of the world as a huge financialeconomic system, in which people, information, and cultural patterns (not to mention money, information, etc.) move more and more freely. ${ }^{3}$ To put it bluntly, the feeling of a new unity of the world with its state borders melting into the air was more powerful than all these vague concepts and subtle distinctions. The social scientists were more fascinated by the destruction of the old borders than they were interested in the new borders emerging in a seemingly borderless world. As Joachim K. Blatter formulated, "I argue that insights from border regions are useful contributions to the debate on 'debordering the world of states" (Blatter, 2001: 179). Thus, the "debordering of the states" was the main trend of the decade.

However, theories go their ways; they do not (only) mirror reality, but often say something very important in advance. Theories of globalization had their predecessors in times of firm borders that were taken for granted, at least in Europe after the World War II. In the middle of the seventies, Niklas Luhmann suggested a concept of the world society that was more sophisticated and, seemingly, had nothing to do with the world divided into territories controlled by the large military blocks (Luhmann, 1975). World society, according to Luhmann, was not identical with global society. ${ }^{4}$ Theoretically, he had constructed the concept more accurately. ${ }^{5}$ Luhmann described the same phenomena as the proponents of globalization. The old notion of society, Luhmann said, suggested that society is territorial because the main system of society is the political system, i.e., the state, and the state is a territorial entity. Then, in the course of the socio-cultural evolution, the economic system is prioritized over the political system. Society would then be considered as an economy that is not limited to the territory of the state; at the same time, it is becoming increasingly international. However, the differentiation of social systems

\footnotetext{
1. In his next book, Ohmae proclaimed the "end of the Nation State" (Ohmae, 1995).

2. Cf.: Robertson, 1992: $57,59$.

3. Cf.: Robertson, 1995; Nederveen Pieterse, 2004; Bauman, 2013. For a general review see: Haque Khondker, 2004 .

4. Luhmann elaborated and modified his theory until the end of his life, and his arguments of the goties are not the same as they used to be in his early writings. However, several general points concerning world society did not change significantly.

5. Other theories of the world society were elaborated largely without noticing Luhmann's argument. Cf. Greve, Heintz, 2005, on the "parallel discovery" of the world-society by Niklas Luhmann, Peter Heintz and John Meyer. I think, their contribution is significant enough to be mentioned here. However, they are far less rigorous in their arguments than Luhmann. Cf. e.g.: "A considerable body of evidence supports our proposition that world society models shape nation-state identities, structures, and behavior via worldwide cultural and associational processes" (Meyer et al., 1997: 173). It is right, but hardly needs a sophisticated theory of space and territory.
} 
continues. Now, you cannot say that a society is primarily state, or primarily economy (Wirtschaft). Society is the largest social system, which encompasses all systems, except territorially. It means that all the systems of the world society are world systems; economy and science, news information systems, and even education become international. In developing the concept of the world society, Luhmann emphasized that space loses its value. The development of telecommunications systems allows one to almost instantly overcome vast distances. This means that there is no difference between large and small distances; it means that everything occurs simultaneously. Now, changes on the New York or Tokyo stock exchanges have an immediate worldwide effect. Now, information comes immediately via television and the global electronic network. Now, one can live in one place and work thousands of miles away through the same communication network. These arguments have been repeated many times by many scholars. They combine empirical evidence, at least partly incontestable, with theoretically more vulnerable reasoning. What makes them vulnerable is their logical purity.

The global world has no boundaries. The world society definitely has no boundaries. This may seem trivial. However, if the global world has no external borders, it cannot be composed of restricted areas. It means that all the bordered areas of the global or world society are not its parts. At first glance, this seems to be a purely logical paradox; through the addition of a limited amount of locations (areas of limited size) you will never get as a result an infinite space. Then, the global world has to have borders. There are no outer borders of the global society, however, because there are no other territories behind, that is, no territories except those included into the space of the global society. There is only one way to overcome this difficulty. It must be recognized that the space of the global world is of a different nature. It is impossible to divide this space into separate fragments to get a set of several territories, say, of different states. It is an un-territorial space that cannot be divided into smaller territorial parts.

Therefore, the territorial principle of the organization of social life and the design of the world society are fundamentally different. When we travel and leave a territory, when we cross a border of any state, we do not find ourselves in a global society; we find ourselves in another state, in contested zones, or in some neutral area. However, we never get into the global society, which has no place, and no places at all. Where is the "worldsocietal", or the "global", then?

Is it possible that cities, especially modern global cities, are the sites of this kind? According to Saskia Sassen, cities are those territories which "are subnational", but are of particular importance for the functioning of global networks as their central places. This is one of her crucial arguments; "In the 1980s, finance and specialized services emerged as the major components of international transactions. The crucial sites for these transactions are financial markets, advanced corporate service firms, banks, and the headquarters of transnational corporations (TNCs). These sites lie at the heart of the process for the creation of wealth, and they are located in cities" (Sassen, 2000: 11). She confronts cities and nation-states, their territoriality being "understood as exclusive institutionalized authority over its territory"; what is located in cities "cannot be seen as constitutive 
of the state's exclusive territoriality. This is the type of framing of the relationship between territoriality and state authority that comprises forms of globality constituted via localized actors encased in local places. The relationship between territory and state authority today can accommodate the existence inside national territory of denationalized spatialities" (Sassen 2006, 418). Social scientists often describe similar phenomena in a similar vein. For example, in the middle of the eighties, David Harvey wrote about the city as a "competitive unit within the uneven geographical development of global capitalism" (Harvey, 1985: 198). More recently, he draws attention to the "urbanization process that has now become genuinely global, in part through the astonishing global integration of financial markets" (Harvey, 2012: 12). In global cities, there are organizations located within that are included in international relations; "the corporatization of economic life across territorial boundaries is taking many forms" (Amin, Thrift, 2002: 64). Therefore, "We cannot claim territorial integrity for cities in this context" (ibid.: 65). I will not multiply quotations. You see, historically, the city was the place of power and solidarity; the very idea of the citizenship was born from city life. Now, they are spatial formations without boundaries, giving place to the nodes of international networks, and different movements that are global but localized in some spots of the cities. What about nation-states then? Craig Calhoun answers the question with a rather moderate argument; "We need not leap to the conclusion that globalization is fatally weakening the nation-state to see the prominence of both solidarities and activities that cross borders and ways in which transnational organizations and links may work to empower subnational regions or other groupings" (Calhoun, 2007: 108). It is a reasonable, well-balanced argument, but it hardly encourages us to formulate more risky conclusions. Nation-state and globalization are not balanced in reality as well as they are balanced in theory.

Twenty years ago, when the proponents of globalization proclaimed the decline, if not the end, of the state, Michael Mann wrote "The nation-state is thus not in any general decline, anywhere. In some ways, it is still maturing. However, even if it were declining in the face of the supranational forces ... it is still gaining at the expense of the local, the regional, and especially the private forces. The modern nation-state remains a uniquely intense conception of sovereignty" (Mann, 1993: 118). This sovereignty covered, according to Mann, military, economic, and "other civilian" issues. He saw the nation-states activities and agencies intermingling with international, mostly European, institutions, everywhere. He was sure that states would not disappear in the next decades. We can say now that Mann was right. The states are still there as territorial political entities. Only states, (at least large powerful states), despite globalization, can combine their special kind of solidarity of large groups of people (their political nations) with financial, military, and police resources, which no city, no corporation, and no international organization possesses. As seen by the classical sociological tradition, the territories of the sovereign states are the true places of society. In what follows, I shall combine two classical, well-known, 
and seemingly, very simple arguments to demonstrate, in a purely formal, ideal-typical way, a couple of logical consequences of this view for contemporary sociological discussions.

In a classical definition, Max Weber wrote: "[T] he state is the form of human community that (successfully) lays claim to the monopoly of legitimate physical violence within a particular territory - and this idea of 'territory' is an essential defining feature" (Weber, 2004: 33). These are well-known but often misunderstood words. At least sociologists would pay much more attention to the "legitimate violence" and "monopoly" than to "particular territory." They fail to consider, in a due way, that this "monopoly of legitimate violence" exists only in a certain area (the translators added the word "idea" that is absent in the original German version). This means that the physical violence of the state in peaceful times (because wars do not know either legitimacy or monopoly of violence), cannot reach behind the state border. The state territory is a space separated from the spaces of other states. This is the area where the bodies of the citizens stay (the bodies of the citizens are the majority of the people's bodies, strictly speaking). The state territory is a kind of container for them; the majority do not go in "outer spaces." Traveling is a rare privilege of a minority, and has no influence on the main features of the state-territorycontainer. This is how the most obvious fact is constructed; a state has its own territory, no other states can occupy the same territory at the same time, and most people there are the citizens of the state who can be legitimately reached in this territory with the state's tools of physical violence. This makes the state a rare, if not a unique, social formation. Other social formations, such as organizations, may jointly dispose of buildings or move from one building to another; as well, families can change their living quarters in modern societies, etc. Even a city, (more precisely, an urban community), while keeping its name, can move to a new location. A state, in most cases, cannot be divorced from its territory. If it changes its locale, it means a change of the state itself. Weber's contemporary, Georg Simmel, called this feature the "exclusivity of space." One "piece of space" (Raumstück) or "space area" (Raumgebiet), say, entails that a place excludes all the other areas simply due to its location. If a social entity belongs to this piece of space, the exclusivity of space, according to Simmel, becomes its specific feature. State, he continued, has this exclusivity. To some extent, ancient cities had this exclusivity, too, because they also had boundaries. The territoriality of states is the same as the exclusivity of their spaces. They have their sovereignty over these areas. The most important definition that Simmel provides in his article "The Sociology of Space" is as follows: "The boundary is not a spatial fact with sociological consequences, but a sociological fact that forms itself spatially" (Simmel, 1997: 143). What is the state border then that separates one area from all the others? On the one hand, this is a spatial fact, a real object-in-space. On the other hand, it is a social (and political) fact. The languages, the customs, or the laws are not spatial things; that is, why they cannot be placed only on one side of the spatial border. They are not spatial, so then how can they stay in a spatial container? It is possible because social life consists, according to Simmel, not only in associations, but also in differentiations and separations of people. Simmel believed that spatial boundaries help people to objectify their social 
differences. A border, according to Simmel, is one of the cases of the "spatial projection of social forms". After a border between groups is established, they are better aware of their own identities as territorially-fixed groups. He introduced the notion of "solidarity with a piece of space" to describe people's attitude to the (limited, bordered) territory where they are used to living for a long time. That is why the citizens of a state, closed by its border from the outer world, are not only accessible to the violence of the state, but also can have strong feeling of belonging to its territory. They not only obey the commands of the state, but also love their motherland with its landscapes, cities, and villages.

This argument may seem too abstract and ahistorical to be true. I think it can be partially true in a more complicated and historically substantiated system of arguments. I would like once again to reiterate this logical, formal-sociological approach to make it clearer.

Imagine that there are some more-or-less important differences between large social groups. To give more weight to these differences and to stand apart from each other, they build a wall, or let their border guard watch over the symbolic line that separates them, or agree that a river or a lake would be considered as a boundary between them. If this happens, a river, a lake, or a wall, or a conditional guarded line becomes the most evident feature of their differences. Each group becomes entirely aware of its unity, because it is located on the respective side of the border and feels solidarity with it, i.e., with the area where they are used to living, where the whole way of life is their own. The groups within a state can be still very different, however, even if they are subjected to the same legitimate power. They are made to live together as a single nation, though being far from any true homogeneity. ${ }^{6}$ This living together within a restricted state territory may influence their identification with this area.

It is a special kind of solidarity, not of citizens with each other, but of groups with their "pieces of space". This, in turn, can become the basis of further identifications of groups. Formally, those who belong to the territory are the citizens of the state. Their solidarity with each other is strengthened and/or conditioned by their solidarity with the space. This is an ideal type; citizenship, feelings of territorial belonging, culture and language, and the resident location of population coincide, implying each other. The most interesting cases for sociology are those where something goes wrong, and the scheme does not work. In the modern world, we know of groups that have no territory, and no solidarity with any space. There are groups that identify their territory as an area that does not cover any territory of existing states. There are also groups that are residents on the territories of the states, consisting of people only having feelings of their belonging to the states and their landscapes, but without full citizenship there. Their awareness of border and their social actions and communications only partially refer to the existing borders of nation-states. However, the ideal-type construction of citizenship coinciding with the resident belonging, and civic solidarity would be a useful fiction for a modern state. In other words, national belonging would be identical with the respective citizenship, with

6. Cf. e.g., Todd, Le Bras, 2012, on the diversities of the regions of the classical, seemingly very homogeniuos nation-state. 
all the other features of nation being pure products of education or the re-education of the people. The state would be the acting force of this education of the citizens. The state has its monopoly to violate not only the bodies of the subjects, but also to decisively influence the subjects' feelings of belonging, and the subjects' solidarity with a space.

Nationalist ideologies, however, draw on quite other assumptions. For them, the state would only be a tool of a nation to keep itself alive. Any large group that they are ready to call nation, needs, they say, its own territory. It can only retain its identity on this territory, and it needs a state to keep as their own. Only a state would prohibit any strangers from getting in and becoming aliens-in-the-state. Only a state would introduce rules of "consanguinity" in order to preserve the indigenous culture and language, and to support the economic activities of those who belong to the "nation" on their own territory. These are the principles that the proponents of the modern state would reject because, as they say, the culture itself can be a culture of the free choice of citizenship, and of the principles of association with others. A civic nation is built on the principle that is contrary to the principle of "blood". For a civic nation, its spatial order, the bordered territory of its state is, in fact, the basis of homogeneity; the unanimity of the nation means the solidarity of those who are inside. The formal principle of border thus becomes the basis of solidarity.

Now, we can see the dark side of the arguments both in favor of a nation of blood and culture, and in favor of a civic nation. ${ }^{7}$ The formal principle of border can become the basis for free choices of group identity and homogeneity. Any large group that will assert itself as a nation-like one can declare its homogeneity as a nation within its borders, and struggle to be recognized as a state. It can be, in fact, a matter of free choice, but at the same time, it can be presented to the world as a narrative of blood and culture. The only reason for this group of people to be there is their identification and solidarity with the bordered area, a region, or a piece of space they have chosen as their motherland. However, they would be able to construct a number of narratives about blood, language, culture, and history to present themselves for themselves, and for the outer world as the indigenous population that has its rights of territory and state. Well-known conflicts of the last years provide us with much evidence of this kind; the borders of existing states would be contested by the groups that chose another cultural/national identity for themselves. They would like to reshape the borders, and this is the most important thing. They

7. I can only mention here the discussion of-to use Michael Ignatieff's dichotomy-blood or belonging (Ignatieff, 1993). Two critical arguments seem to be especially relevant and well-formulated here. In a few years after Ignatieff published his book, Bernhard Yack wrote: "It may be reasonable to contrast nations whose distinctive cultural inheritance centers on political symbols and political stories with nations whose cultural inheritance centers on language and stories about ethnic origins. But it is unreasonable and unrealistic to interpret this contrast as a distinction between the rational attachment to principle and the emotional celebration of inherited culture" (Yack, 1996: 197). Yack argued that a liberal construction of the nation-state is false, even for the modern Western States, where national traditions and cultural memory is the basis of what seems a consequence of a free decision of an enlightened citizenship. A few years later, Taras Kuzio, criticizing Hans Kohn, states emphatically; "Western states have evolved from ethnic to civic states only in the last four decades of the twentieth century. Without an understanding of this evolution of Western ethnic into civic states we cannot understand the nature of the civic state as containing tension between its universal liberalist and national particularist components" (Kuzio, 2002: 36). 
converse their territorial identity into the national identity, and reinforce their ambitions by referring to culture and history. A nation has the right to territory, a territory is what a nation wants to have to survive, and a nation is what is there on its territory (or wants this territory, once lost, to be won back). The underlying principle of border can hardly be isolated here as a driving force; however, it helps us to disentangle social constructions from what seems to be the historical and/or natural core of a nation.

III

Any principle of a political nation is, in the long run, the principle of the territorial nation-state. The ambitions of new groups to become a political nation in the modern world run contrary to the processes of globalization. They cannot be described in the wellbalanced manner as the remnants of nationalism, as new regionalisms, etc. This is simply another trend in the time of globalization. Borders between groups re-emerge as state borders, and nations re-emerge as nation-states and state-nations, but they do it in the globalizing, borderless world.

Sociologically, this is most intriguing. Global networks and flows exist in a borderless world; nation-states exist in the world, full of stable and changing borders; world cities enter into new combinations with the bordered world of the nations. That is why borders cannot divide the people with their fragile solidarity living in the world cities. No one acting in the networks of the global world would have a feeling of solidarity with the pieces of territory, or with people who are visible there. However, his house, his body, and the bodies of his relatives are accessible to state-violence. And the state where the respective world-city is placed would be able, nevertheless, to try to imbue the feelings of solidarity in all of its citizens.

The borders are born in the narrative, and objectified in political action.

It depends on a complex constellation of sociological factors whether these borders will remain an important part of the political rhetoric of social movements, or acquire the status of the new state borders in the course of struggles, or even wars.

\section{References}

Amin A., Thrift N. (2002) Cities: Reimagining the Urban, Cambridge: Polity Press.

Bauman Z. (2013) Glocalization and hybridity. Glocalism, no 1, pp. 1-5.

Berezin M., Schain M. (eds.) (2003) Europe without Borders: Re-Mapping Territory, Citizenship and Identity in a Transnational Age, Baltimore: Johns Hopkins University Press.

Blatter J. K. (2001) Debordering the world of states: toward a multi-level system in Europe and multi-polity system in North America?: Insights from border-regions. European Journal of International Relations, vol. 7, no 2, pp. 175-209.

Calhoun C. (2007) Nations Matter: Culture, History, and the Cosmopolitan Dream, London: Routledge. 
Greve J., Heintz B. (2005) Die "Entdeckung" der Weltgesellschaft: Entstehung und Grenzen der Weltgesellschaftstheorie. Zeitschrift für Soziologie, Sonderheft "Weltgeseflschaft", pp. 89-119.

Haque Khondker H. (2004) Glocalization as globalization: evolution of a sociological concept. Bangladesh e-Journal of Sociology, vol. 1, no 2. Available at: http://www. mukto-mona.com/Articles/habibul_haque/Globalization.pdf (accessed 1o December 2014).

Harvey D. (1985) The Urbanization of Capital, Oxford: Basil Blackwell.

Harvey D. (2012) Rebel Cities, London: Verso.

Ignatieff M. (1993) Blood and Belonging, New York: Farrar, Straus, Giroux.

Kuzio T. (2002) The myth of the civic state: a critical survey of Hans Kohn's framework for understanding nationalism. Ethnic and Racial Studies, vol. 25, no 1, pp. 20-39.

Luhmann N. (1975 [1971]) Die Weltgesellschaft. Soziologische Aufklärung, Bd. 2: Aufsätze zur Theorie sozialer Systeme, Opladen: Westdeutscher Verlag, pp. 51-71.

Mann M. (1993) Nation-states in Europe and other continents. Daedalus, vol. 122, no 3, pp. 115-140.

Meyer J. W., Boli J., Thomas G. M., Ramirez F. O. (1997) World society and the nationstate. Journal of Sociology, vol. 103, no 1, pp. 144-181.

Nederveen Pieterse J. (2004) Globalization and Culture, Lanham: Rowman and Littlefield.

Ohmae K. (1990) The Borderless World: Power and Strategy in the Interlinked Economy, New York: HarperBusiness.

Ohmae K. (1995) The End of the Nation-State: the Rise of Regional Economies, New York: Simon and Schuster.

Robertson R. (1992) Globalization: Social Theory and Global Culture, London: Sage.

Robertson R. (1995) Glocalization: time-space and homogeneity-heterogeneity. Global Modernities (ed. M. Featherstone et al.), London: Sage, pp. 25-44.

Sassen S. (2000) Cities in a World Economy, London: SAGE.

Sassen S. (2006) Territory, Authority, Rights: From Medieval to Global Assemblages, Princeton: Princeton University Press.

Simmel G. (1997 [1903]) The sociology of space. Simmel on Culture: Selected Writings (eds. D. Frisby, M. Featherstone), London: Sage, pp. 137-170.

Todd E., Le Bras H. (2012) L'invention de la France: atlas anthropologique et politique, Paris: Gallimard.

Yack B. (1996) The myth of the civic nation. Critical Review, vol. 10, no 2, pp. 193-211. 


\section{Политическая нация и пространственный порядок: к новой взаимосвязи старых понятий}

\section{Александр Ф. Филиппов}

Доктор социологических наук, профессор, руководитель Центра фундаментальной социологии ИГИтИ НИУ ВШЭ

Адрес: ул. Мясницкая, д. 20, г. Москва, Российская Федерация 101000

E-mail: filippovaf@gmail.com

Статья представляет собой отредактированную версию доклада, сделанного на первой всемирной конференции Ассоциации исследователей приграничных земель (Карельский Институт Университета Восточной Финляндии, Йэнсуу). В статье сопоставлены противоположные подходы к пространственному порядку современного общества. C одной стороны, теоретики глобализации и мирового общества настаивают на том, что государства и государственные границы уже не имеют значения. Глобализация означает мир без границ. Поэтому современные глобальные города, хотя и расположены на территориях государств, не включены в их пространства. В мировом городе нет обычной солидарности граждан, в мировое общество не может попасть тот, кто вышел за границы государства. С другой стороны, многое свидетельствует о том, что государства не исчезают. Они по-прежнему играют незаменимую роль. Два классических определения позволяют продвинуться дальше в теоретичеком исследовании. Макс Вебер говорио о монополии на физическое насилие, которой располагает государство га своей территории. Георг Зиммель утверждал, что граница в пространстве - это объективация присущего людям стремления к обособлению друг от друга. Граница государства — это часть пространства, с которой они могут испытывать солидарность. Поэтому государство может не только применять легитимное насилие против тех, кто находится на его территории, но и внушать им чувство солидарности как принадлежности к тем, кто живет на этой территории. Здесь возможны два понятия нациии и два вида национализма. Для более традиционного, ориентированного на «кровное родство», культуру и язык, государство - это орудие самоутверждения нации, которой требуется территория с четкими границами для самосохранения. Второе понятие - это понятие «гражданской нации», которое основано на идее свободного выбора идентичности, в том числе и национальной. Однако приверженцы второго понимания нации не видят его оборотной стороны. Дело в том, что требование обособленности, осознание пространственной границы группы, требование государства для группы, у которой есть границы, и требование границ и государства для группы, свободно выбравшей свою идентичность, тесно связаны между собой. Эта пространственная определенность любой группы, которая может объявить себя нацией и потребовать государства, противоречит современному устройству мировых городов. Для социологов интереснее всего наблюдать за тем, как пересекаются два принципа пространства: мирового общества с его сетями и потоками и новых государств, утверждающих себя в новых границах.

Ключевые слова: нация, национализм, глобальный город, мировое общество, государство, граница 